\section{Ekplorasi Penyaluran Bantuan Subsidi Upah (BSU) Tenaga Kependidikan Non PNS Selama Pandemi COVID-19}

\section{Lala Hucadinota Ainul Amri' ${ }^{*}$, Whan Augustin Ainul Amri $^{2}$}

1Politeknik Negeri Media Kreatif, Jakarta

2Sekolah Tinggi Ilmu Ekonomi Insan Pembangunan, Tangerang

\begin{abstract}
This study aims to explore the distribution of wage subsidy assistance in accordance with the government's objectives, this study will answer whether BSU is right on target and minimizes the spread of the corona virus in the Ministry of Education and Culture. The research method used is exploratory and descriptive. Exploratory is used to provide in-depth explanations, while descriptive is used to analyze the study qualitatively in order to obtain findings and descriptions of a phenomenon that occurs. The results of this study found that; BSU distribution is right on target without any significant obstacles, the distribution mechanism is ineffective in suppressing the spread of the corona virus. Distribution through government banks found technical obstacles in the form of recipient validation which required visiting the channeling bank with a relatively long service time so that it created a potential crowd, even though there had been prevention in the form of strict implementation of protocols but conditions became more complicated where the assistance of teachers and lecturers coincided with government stimulus assistance. Other, so the goal of suppressing the spread of the corona virus is contrary to the results of this study. Further research recommends researching appropriate distribution methods.
\end{abstract}

Keywords:

Education personnel, covid-19, wage subsidy assistance.

\author{
Corresponding Author: \\ Lala Hucadinota Ainul Amri \\ Politeknik Negeri Media Kreatif, Jakarta \\ Email: lalahuca@polimedia.ac.id
}

(C) The Author(s) 2021

DOI: https://doi.org/10.36407/jmsab.v4i1.297

\section{(C) (4)}

CC BY: This license allows reusers to distribute, remix, adapt, and build upon the material in any medium or format, so long as attribution is given to the creator. The license allows for commercial use.

JMSAB

\section{Research Paper}

Management

Received: 26 Feb 2021 Accepted: 18 Jun 2021

Online: 30 Jun 2021

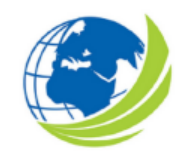

Jurnal Manajemen Strategi dan Aplikasi Bisnis, Vol 4, No. 1, 2021, pp. 181 - 188

eISSN 2655-237X 


\section{PENDAHULUAN}

Pandemi COVID-19 memberikan dampak yang nyata, bukan hanya terjadi di Indonesia, negara diseluruh dunia tercatat melaporkan dampak dari adanya pandemi yang disebabkan virus SARS-CoV-2 ini (Parwanto 2020). Data Kementerian Kesehatan Indonesia melalui Satgas COVID-19 sampai dengan akhir bulan Januari 2020 menunjukkan jumlah kasus terinveksi virus corona lebih dari satu juta jiwa, dengan data tersebut memberikan dampak yang nyata di semua sektor.

Pandemi COVID-19 menjadi kendala bagi semua kalangan di dunia dan ini juga merupakan krisis kesehatan bagi manusia. Dalam dunia pendidikan, pandemi COVID-19 juga memberikan dampak yang luar biasa. Banyak sekolah di dunia ditutup untuk menghentikan penyebaran COVID-19 (Mastura \& Santaria, 2020). Indonesia juga tidak dapat menghindari dampak tersebut, penutupan sementara semua aktifitas untuk menekan penyebaran virus corona. Sektor pendidikan sebisa mungkin dialihkan keluar dari sekolah, diwajibkan bekerja dari rumah (WFH).

Salah satu dampak yang dirasakan di sektor pendidikan adalah penutupan semua lembaga pendidikan dari tingkat dasar sampai tingkat tinggi, semua aktifitas lembaga pendidikan dibatasi dengan ketat, tetapi dengan catatan proses inti lembaga pendidikan dijalankan. Proses belajar mengajar harus tetap dijalankan selama masa penutupan dan pembatasan lembaga pendidikan, regulator pendidikan di indonesia mengeluarkan kebijakan untuk melaksanakan belajar dari rumah dengan menggunakan metode belajar dalam jaringan (online). Masalah muncul tentang pelaksanaan belajar online ini, meliputi kesiapan pendidik, metode penilaian, dan dampak lulusan (Syah, 2020).

Masalah belajar online tersebut telah diketahui Pemerintah, Presiden menerbitkan kebijakan Presiden dalam Inpres nomor 4 tahun 2020 tentang percepatan penanganan COVID-19 melalui refocussing anggaran.

Kementerian Pendidikan dan Kebudayaan (Kemendikbud) menyusun kebijakan untuk mengatasi permasalahan ekonomi yang sangat dirasakan di sektor pendidikan yaitu kurangnya pendapatan bagi tenaga kependidikan (guru, dosen, dan tenaga kependidikan lainnya), khususnya yang berstatus sebagai tenaga kependidikan Non PNS, baik di lembaga pemerintah maupun swasta. Terlebih lagi di lembaga pendidikan swasta, ketahahan lembaga tersebut sangat rentan (Tribunnews 2020). Untuk itulah Menteri Pendidikan dan Kebudayaan memberikan bantuan subsidi upah (BSU) kepada tenaga kependidikan.

Data penerima BSU dikelola oleh Pusat Layanan Pembiayaan Pendidikan (Puslapdik) Kemendikbud, bersumber dari pelaporan periodik (Dapodik dan PDDikti). Kemendikbud meyakini data yang diambil valid dan relaibel karena selain bersumber dari operator lembaga pendidikan yang diawasi di tiap jenjangjangnya, data tersebut juga dicocokkan dengan data Kemnaker dan kartu prakerja untuk memastikan para tenaga kependidikan ini tidak menerima bantuan yang lain (Anisa 2020). Validitas dan reliabilitas data harus didukung penyaluran yang baik, agar tepat sasaran dan menekan penyebaran virus corona.

Tujuan diberikannya BSU untuk melindungi, mempertahankan, dan meningkatkan kemampuan ekonomi tenaga kependidikan dalam situasi pendemi COVID-19. Atas dasar uraian tersebut penelitian ini bertujuan mengeksplorasi penyaluran BSU apakah tepat sasaran dan dapat menekan penyebaran virus corona. Penelitian dilaksanakan dengan 
mempertimbangkan protokol kesehatan, dilaksanakan dengan metode eksplorasi melalui wawancara mendalam dan studi kasus, disamping pengumpulan literasi sebagai studi kepustakaan.

\section{METODE}

Penelitian ini menggunakan metode kualitatif dengan pendekatan fenomenologis dengan melihat situasi di lapangan. Instrumen penelitian berupa wawancara, observasi, dan dokumentasi (Subandi et al., 2019). Metode Deskriptif yang digunakan dengan tujuan menjawab apakah tepat sasaran dan apakah dapat menekan penyebaran virus corona sehingga mendapatkan pemahaman dan pemahaman yang mendalam terhadap topik penelitian. Untuk mendapatkan jawaban yang terstruktur melalui beberapa data Metode Deskriptif juga digunakan sebagai pendukung desain penelitian yang terstruktur.

Sample penelitian ini adalah tenaga pendidikan, yang meliputi dosen penerima BSU sebagai representasi dari dosen, guru penerima BSU sebagai representasi dari guru, tenaga kependidikan sebagai representasi dari tenaga kependidikan baik di sekolah maupun di pendidikan tinggi, perwakilan organisasi profesi PTK, dan Bank penyalur. Penelitian ini memiliki batasan agar pembahasan dan hasil dapat terarah dengan baik. Pembatasan dalam penelitian ini hanya meneliti penerima BSU tepat sasaran dan upaya menekan penyebaran virus corona dalam penyaluran BSU.

\section{HASIL DAN PEMBAHASAN}

Prediksi mengenai adanya suatu pandemi telah ada, sering kali dianggap sebagai statement dari orang atau organisasi tertentu. Pandemi COVID-19 memunculkan paradigma baru karena tidak ada yang tahu bahwa pandemi akan bermuara pada ancaman krisis multidimensi. Krisis ini yang bermula dari sektor kesehatan yang meluas pada sektor luas, termasuk sektor ekonomi dan pendidikan. Tak ada pilihan, selain bergerak bersama untuk mengantisipasi dampak yang timbul akibat pandemi.

Upaya preventif telah dilakukan Pemerintah sejak awal penemuan kasus infeksi pertama virus corona, pemerintah telah mengeluarkan kebijakan untuk mengantisipasi dampak yang ditimbulkan dari pandemi COVID-19. Namun, upaya preventif yang dilakukan tidak sepenuhnya melindungi Indonesia dari penyebaran COVID-19. Sama seperti negara lainnya, Indonesia akhirnya berkutat pada persoalan dampak akibat COVID-19.

Dampak sektor pendidikan yang sangat dirasakan oleh masyarakat adalah penutupan sekolah dari tingkat dasar sampai dengan tingkat tinggi untuk mengurangi kontak orang-orang secara masif. Kebijakan ini diambil pemerintah dalam rangka untuk menyelamatkan hidup banyak orang agar terhindar dari infeksi virus corona.

Dalam menjaga keberlangsungan pendidikan, kegiatan di sektor ini harus berjalan seperti sebelum ada pandemi. Pada saat awal pandemi, belum ada kebijakan tertentu untuk pelaksanaan kegiatan belajar, secara otodidak mengganti pembelajaran kelas menjadi pembelajaran dalam jaringan (daring). Proses tersebut dapat berjalan dengan berbagai masalah yang muncul, sedikit demi sedikit masalah tersebut dapat terselesaikan baik dari pemerintah maupun dari pelaku sektor pendidikan, terdapat dampak lanjutan yang muncul sebagai efek dari perubahan skema pendidikan.

Ada dampak yang harus diantisipasi bagi keberlangsungan pendidikan yang disebabkan oleh pandemi Covid-19. Dampak itu adalah keberlangsungan proses belajar mengajar yang dilaksanakan oleh tenaga kependidikan. Mereka diharuskan melaksanakan proses pembejaran 
dengan kreatifitas masing-masing dengan kewajiban mematuhi protokol kesehatan, semua berjalan dengan normal, walaupun dengan keterbatasan yang ada.

Keberlangsungan proses tersebut mulai terdampak dari sektor yang lain, sektor ekonomi sebagai efek domino dampak pandemi. Daya beli tenaga kependidikan non PNS rendah, pemenuhan finansial siswa terhadap sekolah terganggu, dan lembaga pendidikan swasta rentan terhadap dampak ekonomi yang melemah. Alasan itulah yang mendorong pemerintah melalui Kemendikbud memberikan Bantuan Subsidi Upah (BSU) sebagai stimulus untuk melindungi tenaga kependidikan yang terdampak akibat pelemahan ekonomi.

Stimulus BSU tersebut memiliki peran ganda, selain untuk menjaga ketahanan ekonomi dan mendukung keberlangsungan pelaksanaan pembelajaran oleh tenaga kependidikan, manfaat lainnya adalah menjaga penyebaran virus corona, pemerintah menganggap dengan diberikan stimulus akan menambah penghasilan sehingga tenaga kependidikan tersebut dapat fokus bekerja dari rumah (WFH).

Data penerima diyakini oleh Kemendikbud merupakan data Valid dan reliabel yang bersumber dari Puslapdik berdasarkan laporan priodik yang bersifat wajib dan terawasi disemua jenjang lembaga pendidikan.

\section{Penerima BSU Tepat Sasaran}

Dalam mendata penerima BSU, Kemendikbud menggunakan Data Pokok Pendidikan (Dapodik) dan Pangkalan Data Dikti (PDDikti). Semua data tenaga kependidikan terdata, identitas lengkap termasuk status kepegawaian, sehingga bantuan akan sulit dimanipulasi maupun kemungkinan penyalahgunaan. Jumlah penerima BSU tenaga kependidikan non PNS berjumlah 2.034.732 orang, dengan rincian 162.277 dosen non PNS pada PTN dan PTS, 1.634 .832 guru dan pendidik pada satuan pendidikan negeri dan swasta, dan 237.623 tenaga kependidikan lainnya (tenaga perpustakaan, laboratorium, dan administrasi sekolah).

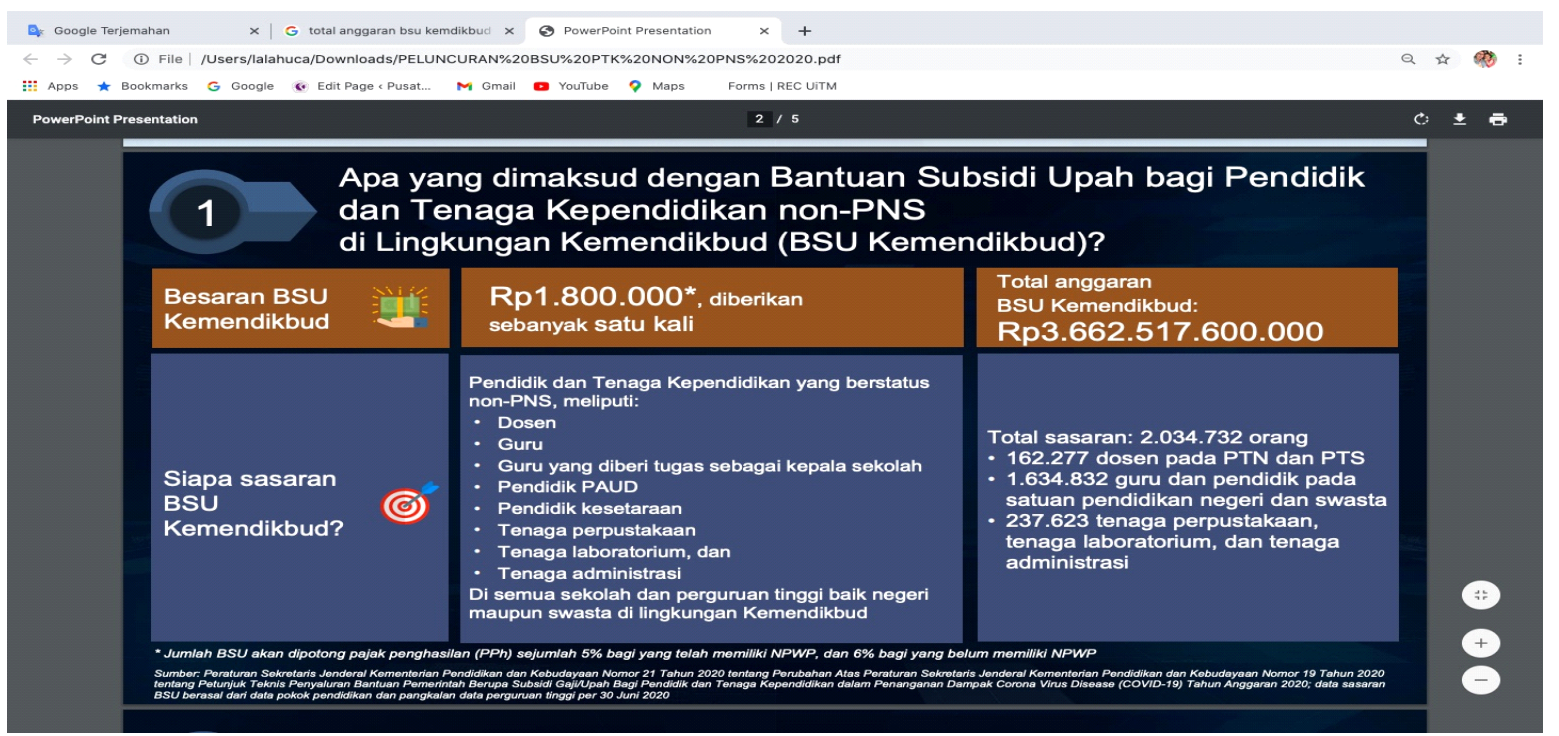

Gambar1.

BSU Kemdikbud (kemdikbud.go.id, 2020) 
Total anggaran bantuan subsidi upah (BSU) dari Kemendikbud sebesar Rp.3.662.517.600.000,00. Anggaran tersebut dialokasikan dari APBN melalui realokasi anggaran kemendikbud sesuai dengan PP nomor 1 tahun 2020 dan Inpres nomor 4 tahun 2020. Pedoman pelaksanaan teknis penyaluran BSU diperkuat dengan Permenkeu Nomor Nomor 38/PMK.02/2020 dan Permendikbud Nomor 44 Tahun 2020.

Sumber data penerima BSU adalah data Pusat Layanan Pembiayaan Pendidikan (Puslapdik) Kemendikbud, Puslapdik mengambil Data Pokok Pendidikan (Dapodik) dan Pangkalan Data Dikti (PDDikti) yang dikelola oleh Dirjen PAUD Dikdasmen, Dirjen Dikti, dan Dirjen Diksi, munculnya rantai koordinasi ini perlu di perhatikan secara serius untuk mengurangi miss-data yang mungkin terjadi. Hal ini dikuatkan oleh sekretaris Himpaudi sebagai perwakilan organisasi PTK menyebutkan: "data dapodik saya yakin valid, dilaporkan oleh operator satuan pendidikan tiap semester, diverifikasi oleh kepala satuan pendidikan dan dinas terkait". Pendapat tersebut menguatkan proses pengambilan data yang bersumber dari tingkat pelaksana paling bawah, sehingga dipercaya akan tepat sasaran.

Penyusunan data penerima BSU disusun berdasarkan penarikan data dari Dapodik dan PDDikti pada tanggal 30 Juni 2020, hal ini menimbulkan sedikit masalah mengenai sinkronisasi data Dapodik dan PDDikti jika ada perubahan data, baik itu perpindahan data PTK maupun PTK Baru. Hal ini diperkuat dari studi literasi yang dilaksanakan serta dari wawancara mendalam dari sample yang dipilih. Nilai dampak penarikan data ini tidak terlalu signifikan tapi tetap harus dipertimbangkan.

Masalah selanjutnya yang ditemukan adalah seleksi CPNS tahun 2018, sebagian besar CPNS tersebut sudah menjadi PTK non PNS di berbagai lembaga pendidikan. CPNS tersebut tercatat dalam Dapodik dan PDDikti, hal ini menimbulkan masalah tersendiri. Menyadari hal itu, Kemendikbud mengeluarkan syarat pelengkap pencairan BSU dengan Surat Pernyataan Tangung Jawab Mutlak (SPTJM). Hal ini berfungsi sebagai pelindung dana BSU agar tepat sasaran, bilamana dikemudian hari ditemukan pelanggaran oleh oknum, surat ini akan digunakan sebagai pelindung pengembalian anggaran negara.

Dari uraian tersebut, dapat disimpulkan bahwa terdapat temuan beberapa permasalahan, tetapi permasalahan tersebut telah memiliki antisipasi agar dapat meminimalkan penyalahgunaan anggaran oleh oknum tertentu. Berdasarkan kajian eksploratif, kajian literasi dan kebijakan maka penerima BSU dinyatakan tepat sasaran melalui kajian secara kualitatif dengan sumber Data Dapodik dan PDDikti berasal dari laporan periodik instansi pendidikan melalui operator dengan validasi yang ketat sesuai dengan jenjang dan kewenangan dipercaya valid dan reliable sehingga penerima bantuan tepat sasaran by name by address.

\section{Menekan Penyebaran Virus Corona}

Keberlangsungan proses pendidikan mulai terdampak dari sektor yang lain, sektor ekonomi sebagai efek domino dampak pandemi tak bisa dihindarkan. Daya beli tenaga kependidikan non PNS rendah akibat dampak ekonomi yang melemah. Pemerintah melihat hal ini sebagai masalah besar, selama pandemi tenaga kependidikan non PNS mengeluh dengan kebutuhan sarana dan prasarana yang harus ada selama kerja dari rumah (WFH), sementara kegiatan di sekolah banyak yang ditunda atau dibatalkan, secara langsung berdampak pada tambahan penghasilan mereka. Selain itu lembaga pendidikan swasta yang rentan terhadap pelemahan ekonomi juga terasa, daya tahan lembaga tersebut diuji.

Efek lanjutan dampak pandemi menyebabkan tenaga kependidikan non PNS banyak yang mencari tambahan penghasilan untuk mencukupi kebutuhan tersebut, efek lanjutan jika fenomena ini dibiarkan akan memberikan dampak yang kontradiktif terhadap kebijakan menekan penyebaran virus corona. Untuk itu pemerintah mengeluarkan kebijakan BSU agar tenaga 
kependidikan non PNS dapat fokus melaksanakan tugasnya dari rumah agar dapat menekan penyebaran virus corona dengan meminimalkan kontak ke lingkungan luar.

Pemerintah merancang penyaluran BSU secara non tunai. Dari kajian literasi yang ada serta diyakinkan hasil analisa wawancara mendalam, manfaat non tunai ini dapat menekan penyebaran virus corona. Uang tunai baik logam maupun kertas disebut menjadi media peredaran virus corona. Hal ini karena bahan logam dan kertas memiliki risiko tinggi untuk penyebaran virus. Untuk menekan penyebaran virus, BSU disalurkan melalui skema penyaluran nontunai.

Penyaluran non tunai dilaksanakan oleh bank pemerintah, ada 4 bank pemerintah sebagai penyalur. Hasil wawancara mendalam menemukan masalah baru, terdapat antrian yang menyebabkan munculnya potensi kerumunan, hal ini diakibatkan oleh jumlah penerima BSU yang banyak. Hal tersebut sudah diantisipasi oleh bank penyalur, dengan penerapan Protokol kesahatan, social distancing, pembatasan jumlah layanan tiap hari, pembatasan jumlah orang dalam ruangan bank, dan menyediakan ruang tunggu outdoor. Sesuai dengan pernyataan customer service salah satu bank penyalur: "proses by name by address sudah bagus, hanya saja perlu membuka rekening baru yang mewajibkan penerima datang ke bank, ini yang menyebabkan kerumunan, padahal saya yakin tiap penerima sebagian besar pasti sudah punya rekening bank". Analisa responden mencatat kerumuman dan antrian dalam waktu yang lama tetap saja terjadi, walaupun dengan antisipasi yang ada, usaha tersebut belum bisa efektif dalam menekan potensi penyebaran virus corona.

Temuan lain di lapangan menemukan 2 faktor yang menghambat menekan penyebaran virus corona. Pertama, faktor bank penyalur tidak hanya menyalurkan BSU untuk PTK, tetapi menyalurkan pula bantuan subsidi program pemerintah lainnya, sehingga menimbulkan potensi kerumunan yang masif, serta menambah waktu tunggu untuk mendapatkan layanan, setidaknya dari sample terpilih ditemukan mayoritas menghabiskan waktu rerata 3-6 jam untuk mendapatkan layanan bantuan subsidi pemerintah, tentu hal ini menghambat kegiatan mereka untuk Work from home. Kedua, skema penyaluran melalui pembukaan rekening baru yang ditetapkan oleh pemerintah, mewajibkan penerima BSU untuk datang ke bank, sekedar verifikasi, validasi dan mengisi kelengkapan data yang dibutuhkan bank. Hal ini sangat tidak efektif seperti yang disampaikan oleh bank penyalur, untuk itu dari temuan ini diharapkan ada kebijakan baru agar temuan ini tidak lagi kontradiktif terhadap upaya menekan penyebaran virus corona.

Dari uraian tersebut, skema penyaluran non tunai dianggap efektif untuk memangkas birokrasi dan meminimalkan penyalahgunaan bantuan. Akan tetapi akan jadi kontradiktif dimana harapan untuk menekan penyebaran virus corona melalui penyaluran non tunai membuat masalah baru yang diakibatkan keharusan penerima untuk melakukan proses validasi rekening baru di bank penyalur. Solusi yang ditawarkan dapat berupa penggunaan rekening eksisting yang dipunya penerima atau dengan data yang sudah lengkap dan valid, penerima dapat datang ke bank penyalur tanpa proses validasi yang memakan waktu lama.

\section{KESIMPULAN}

Bantuan Subsidi Upah (BSU) untuk Pendidik dan Tenaga Kependidikan di lingkungan Kementerian Pendidikan dan Kebudayaan bermanfaat selama Pandemi COVID-19, melindungi tenaga kependidikan yang terdampak akibat pelemahan ekonomi sehingga dapat melaksanakan tugas dan kewajibannya dengan memperhatikan protokol kesehatan. BSU tersebut bersumber dari Data Pokok Pendidikan (Dapodik) dan Pangkalan Data Dikti (PDDikti) yang dikelola Pusat Layanan Pembiayaan Pendidikan (Puslapdik) Kemdikbud. Sumber data tersebut berasal dari laporan periodik operator lembaga pendidikan yang 
diawasi di tiap jenjangnya, sehingga validitas dan reliabilitasnya sangat baik untuk mendukung penerima BSU tepat sasaran. Penyaluran BSU secara non tunai ditujukan untuk memangkas birokrasi, sehingga meminimalisir upaya penyalahgunaan, selain itu mendukung penekanan penyebaran virus corona, temuan lain yang jadi perhatian adalah munculnya potensi kerumunan baru dan lamanya waktu layanan di bank penyalur yang kontradiktif terhadap upaya menekan penyebaran virus corona.

Penelitian ini merekomendasikan penelitian lanjutan untuk meneliti seberapa besar pengaruh potensi kerumunan dan lamanya waktu layanan terhadap potensi penyebaran virus corona. Penelitian tentang metode penyaluran yang efektif untuk menekan penyebaran virus menjadi rekomendasi kedua dari penelitian ini.

\section{REFERENSI}

Aji, Rizkon HS. (2020). Dampak Covid-19 pada Pendidikan di Indonesia: Sekolah, Keterampilan, dan Proses Pembelajaran. Jurnal Sosial \& Budaya Syar-i, 7(5), 395-402. https://doi.org/10.15408/sjsbs.v7i5.15314

Amri, L. H. A., \& Wijayanti, R. A. (2019). Pemanfaatan Sistem Informasi Geospasial Online Untuk Mendukung Pengambilan Keputusan Pemanfaatan Tata Ruang. Jurnal Teknologi Informasi Dan Terapan (J-TIT), 6(2), 62-66.

Amri, L. H. A. (2014). Pengaruh Kepemimpinan Transformasional Dan Iklim Sekolah Terhadap Kinerja Guru Dimediasi Kepuasan Kerja. Program Pascasarjana, Unisbank.

Anisa, Dina Fitri. (2020). Kemdikbud: Data Penerima Subsidi Upah Guru Sudah Lengkap. $\begin{array}{lllll}\text { Nasional Berita } & \text { Satu, } & 19 & \end{array}$ https://www.beritasatu.com/nasional/700533/kemdikbud-data-penerima-subsidiupah-guru-sudah-lengkap

Bairagi, V., \&Mousami, V. M. (2019). Research Methodology. CRC Press.

Kementerian Keuangan. (2020). Peraturan Menteri Keuangan Republik Indonesia Nomor 38/PMK.02/2020. JDIH Kemenkumham.

Kementerian Pendidikan dan Kebudayaan. (2020). Peraturan Menteri Pendidikan dan Kebudayaan Republik Indonesia Nomor 44 Tahun 2020. JDIH Kemenkumham.

Kementerian Pendidikan dan Kebudayaan. (2020). Peraturan Sekretaris Jenderal Kementerian Pendidikan dan Kebudayaan Nomor 21 Tahun 2020. JDIH Kemenkumham.

Kementerian Pendidikan dan Kebudayaan. (2000). Buku Saku Bantuan Subsidi Upah (BSU). Kemdikbud.

Parwanto, MLE. (2020). Virus Corona (2019-nCoV) penyebab COVID-19. Jurnal Biomedika dan Kesehatan, 3(1), 1-2.

Pemerintah Republik Indonesia. (2020). Peraturan Pemerintah Nomor 1 Tahun 2020. JDIH Kemenkumham.

Pemerintah Republik Indonesia. (2020). Instruksi Presiden Nomor 4 Tahun 2020. JDIH Kemenkumham.

Rangkuti, Freddy. (2013). RisetPemasaran. GramediaPustakaUtama

Subandi., \& dkk. (2019). Implementation of Multicultural and Moderate Islamic Education at the Elementary Schools in Shaping the Nationalism. Tadris: Jurnal Keguruan dan Ilmu Tarbiyah, 4(2), 247-255.

https://doi.org/10.24042/tadris.v4i2.5003

Tribunnews. (2020). Sekolah Swasta Paling Rentan Terdampak Saat Pandemi. Editor: Dana Delani.

https://www.tribunnews.com/kilas-kementerian/2020/06/28/sekolah-swastapaling-rentan-terdampak-saat-pandemi 


\section{Competing interests}

The authors declare that they have no competing interests.

\section{Funding.}

The authors received no financial support for the research and publication of this article.

\section{About the Authors}

Lala Hucadinota Ainul Amri, S.Pd., S.M., M.Si. is a lecturer in management and creative economy at the Department of Printing and Packaging, State Polytechnic of Creative Media, Jakarta. He is a Ph.D. student at Universiti Teknologi MARA, Malaysia. He holds a Master's degree in management science from Stikubank University. Has a bachelor's degree in physics education and a bachelor's degree in management. He has researched various issues in management, arts and social topics.

Whan Augustin Ainul Amri, S.E., M.M. is a lecturer at the Department of Management, STIE Insan Pembangunan, Tangerang. He holds a Master's degree in management from Mercu Buana University. Has a bachelor's degree in management. 